V.S. Chabaniuk, PhD in Physics and Mathematics, E-mail: chab3@i.ua

Institute of geography of the National academy of sciences of Ukraine

$$
\text { O.P. Dyshlyk, }
$$

E-mail: dyshlyk@geomatica.kiev.ua

"Geomatic Solutions" LLC

\title{
NATIONAL SPATIAL DATA INFRASTRUCTURE (NSDI) OF UKRAINE: WHAT ARE ITS ACTUAL, FEASIBLE AND SIMULTANEOUSLY "CORRECT" MODELS?
}

Resume. The actual, feasible and simultaneously "correct" models of digital NSDI of Ukraine are considered in the work. A model of the existed digital NSDI system of Ukraine is named "actual". This model already differs from the model defined by the Law of Ukraine "About NGDI" [1]. As the latter is unlikely to be implemented in the near future, the issue of the digital feasible NSDI model of Ukraine in the next five years, which would take into account the actual model, is especially acute. In addition to feasibility, such a model must also be "correct", what is proposed in the article. The "correct" is called a model, the truth of which can be established by inductive or deductive reasoning. To do this, the correct model must be formalized enough so that everyone can verify the authors' reasoning independently.

Understanding both actual and correct models of NSDI of Ukraine will help to properly organize and develop actual Spatial Infrastructure Activities (SpIA) in Ukraine, including the real ${ }^{1}$ implementation of the Law [1]. Although the results of the article call into question its feasibility and substantiate an alternative viewpoint on the automation problem of NGDI/NSDI/SpIA. However, we are convinced that it is still possible to change the alternative viewpoint to a cooperative one, if by means

${ }^{1}$ Real. 1. Which exists in reality, true. Is used with: reality, life, existence, conditions, circumstances, fact, danger, force, wages, income. 2. One that can be implemented, executed: a real plan, a real program, a real task, a real deadline. 3. Which is based on taking into account and assessing the real conditions of reality: a real approach, a real view, a real policy.- accessed 2021-feb-14, http://slovopedia.org.ua/32/53408/32016.html (Ukrainian). 
of by-laws the models of NGDI (Law), NSDI (article) and, finally, SpIA are agreed upon.

To prove the "correctness" of the feasible NSDI model, the theory of Relational cartography and its two main methods are used: Conceptual Frameworks and Solution Frameworks. In addition, the correspondence between Relational cartography and Model-Based Engineering is used.

Key words: NSDI; product model; process model; actual, feasible and "correct" model

\section{Introduction. Purpose}

The term "National Spatial Data Infrastructure" (NSDI) is understood more broadly than "National Geospatial Data Infrastructure" (NGDI), at least because the meaning of the term "spatial" includes the meaning of the term "geospatial". Ukraine's NSDI is inextricably linked to Spatial Infrastructure Activities (SpIA) in Ukraine. In fact, research on SpIA related with NSDI is more important than vice versa. Of practical interest are only NSDI and SpIA or their important parts, between which the dualism relations is true. An example of such a dualism can be formulated as follows: it is impossible to operate with NSDI without SpIA, and modern SpIA is impossible without digital NSDI. This dualism is a kind of "process $\leftrightarrow$ product" dualism, where the process is SpIA and the product is NSDI.

SpIA is an objective reality, the part of which, suitable for automation and related to digital NSDI, we can and should perceive through its models: actual, feasible and "correct". The actual model is called the real model at the moment. Apparently, we can talk about 2020-2022, although the current NSDI of Ukraine changes frequently. Implemented in 2022-2026 and at the same time "correct" model should take into account the actual model and be constructive, suitable for implementation in the form of a system in the specified period. A model is called correct, the truth of which can be rigorously substantiated. As a rule, the required rigor is possible in the presence of appropriate, preferably mathematical, formalism. It is understood that the feasible model may be "wrong", which is most often 
manifested in the inoperability of the automated system, which corresponds to this model. In the presence of dualism, the actual and correct models of SpIA correspond to the actual and correct models of NSDI.

It is easy to see that the SpIA is the "primary" and the NSDI domain is the "secondary" objective realities. SpIA is the primary reality, as it existed in nonautomated form in Ukraine long before the digital era of SpIA/NSDI in the early 1990 s, when the terms "digital" NSDI or NGDI began to be used. Automation of SpIA is the most correct beginning of SpIA $\leftrightarrow$ NSDI dualism realization from the viewpoint of computer science. Because in classic methodologies it is recommended to begin the creation of information system on studying of business activity in subject domain, first of all there is SpIA. It is quite obvious that due to the dualism of SpIA $\leftrightarrow$ NSDI, the automation of SpIA will lead to the creation of a corresponding digital NSDI.

The automation of the SpIA $\leftrightarrow$ NSDI dualism can also begin with the creation of a digital NGDI "almost from zero", if, for example, we agree that there is no domain and the digital NGDI itself in Ukraine. In this case, you will have to automate a non-existent reality and create it at the same time, so the domain of digital NSDI (NGDI) is called a secondary reality. Historically, the creation and/or development of the SpIA $\leftrightarrow$ NSDI dualism in the digital era begins/continues with the NSDI in the presence of a SpIA. In this work, we follow this tradition - we consider NSDI models, although the main interest is the SpIA models.

It is difficult to say which of the two approaches to the beginning of the implementation of dualism SpIA NSDI is more complicated: SpIA $\leftrightarrow$ NSDI or NSDI $\leftrightarrow$ SpIA. In fact, we need to talk not about the beginning, but about continuing the implementation, so everything is much more complicated. First, some digital NSDI of Ukraine already exists. Although this is not the system defined by the Law [1]. Second, modern models for the development of Spatial Data Infrastructures (SDI), including NSDI, make it possible to combine both SpIA and NSDI models. The original NSDI models about 30 years ago were the so-called product models. 
Over time, they developed first in the process, and then in the SES (Spatial Enabled Society) model.

In the most general case, SpIA $\leftrightarrow$ NSDI models are needed for: 1) research, 2) design. The most necessary are the models of SpIA $\leftrightarrow$ NSDI, which are (theoretical and practical) constructs, namely: 1) theoretically substantiated and 2) practically feasible. The purpose of the article is to describe and substantiate the following two models of NSDI of Ukraine:

- Actual (real) as of 2020-2022.

- Correct and feasible in 2022-2026.

\section{Overview of NSDI models. Problem and solution method}

The presence of a large number of (N)SDI models is evidenced by a large number of definitions of (N)SDI [2], as the definition of the term reflects the author's view of the definition of the subject. And this representation is definitely not a subject, but, at best, its model, which is reflected in the knowledge of the definition author.

Perhaps the most correct initial and at the same time the most general idea of NSDI models can be obtained from the experience of the so-called "Australian school". Important here are the models of SDI development, considered in the dynamics for more than 30 years, and their scale, shown in Fig. 1. Fig. 1 is created by supplementing the column "3-rd Generation" (conditional beginning - 2010) to the figure "Relationship between the first and second generations of SDI development and product (in origin - product-based) and process (in origin - process-based) SDI development models" from [3]. We call the 3-rd Generation model by the "SES model of SDI development". The attributes of this model are the six shown in Fig. 1 elements of SES [4].

1-st Generation product models are best known from their definition of NSDI [5]: "The national SDI consists of four main components: the institutional framework, technical standards, fundamental data sets, and the network of data exchange centers. The institutional framework defines policies and administrative mechanisms for building, maintaining, accessing and applying standards and datasets. 
Technical standards define the technical characteristics of fundamental data sets. Fundamental datasets are produced in an institutional framework and fully comply with technical standards. The network of data centers is a means by which basic data sets become available to the public, in accordance with the policy set out in the institutional framework and in line with technical standards".

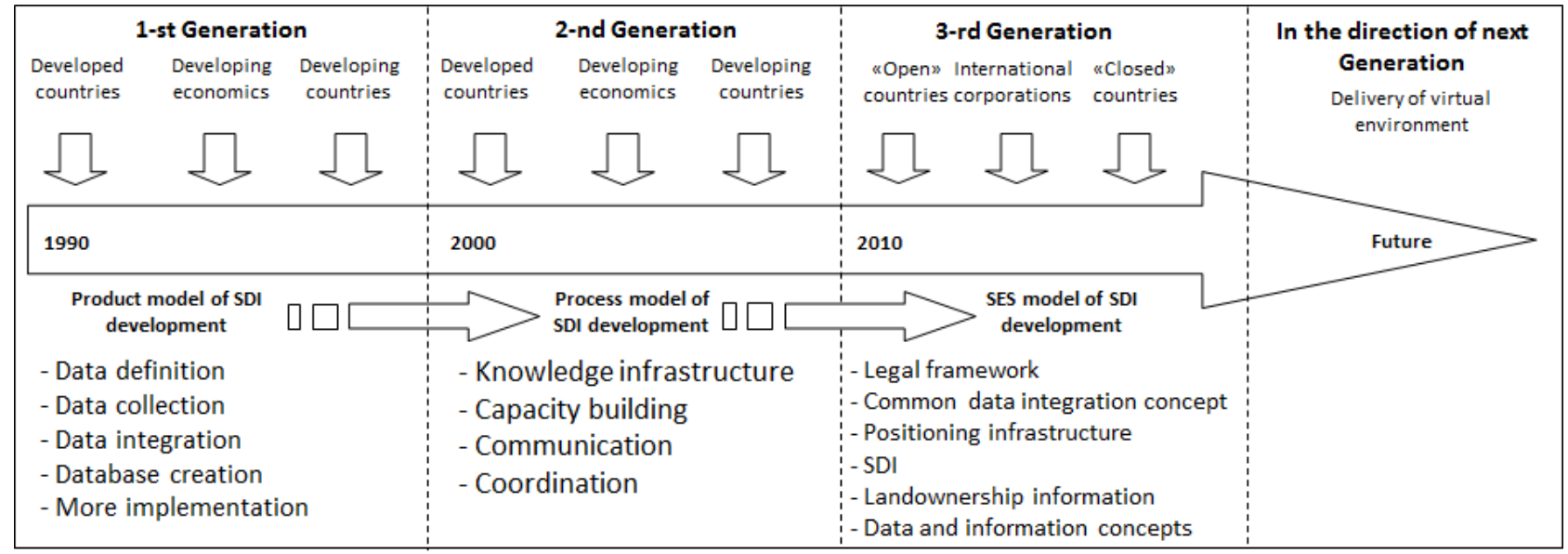

\section{Fig. 1 - Relations between the three Generations of SDI development}

To confirm the "most famous" four-component definition (product model) of NSDI, we recommend a similar definition from [6], which we used at the turn of the millennium. The initial idea of the product and process models of SDI development is given by Fig. 2 [7].

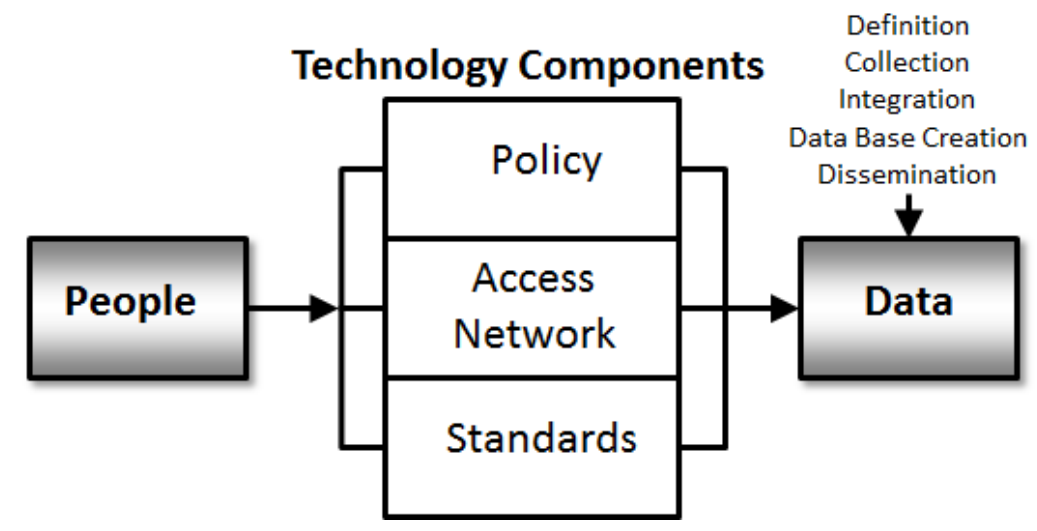

a)

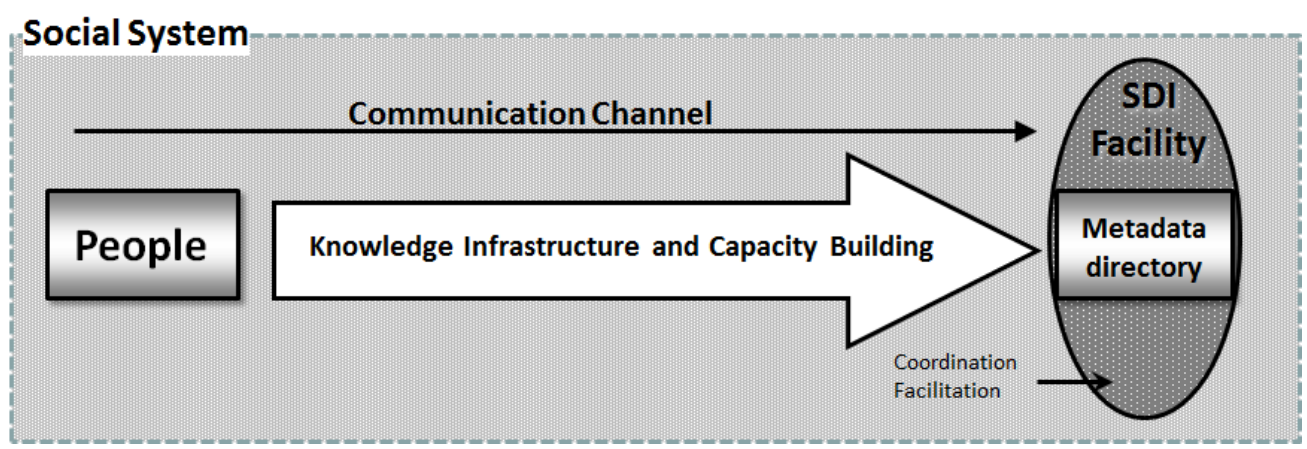


b)

Fig. 1 - a) Product-based model, b) Process-based model [7; Fig. 2]

3rd Generation models are unlikely to be implemented in Ukraine in the next 5 years. Therefore, it is advisable to clarify what the authors meant [7] under the "process" model. To do this, first give their Fig. 3, which is based on the process of Rogers innovative solutions. Rogers' monograph and theory is called "Diffusion of Innovation". It has survived 5 editions. The last, 5th edition [8], even translated into Ukrainian [9].

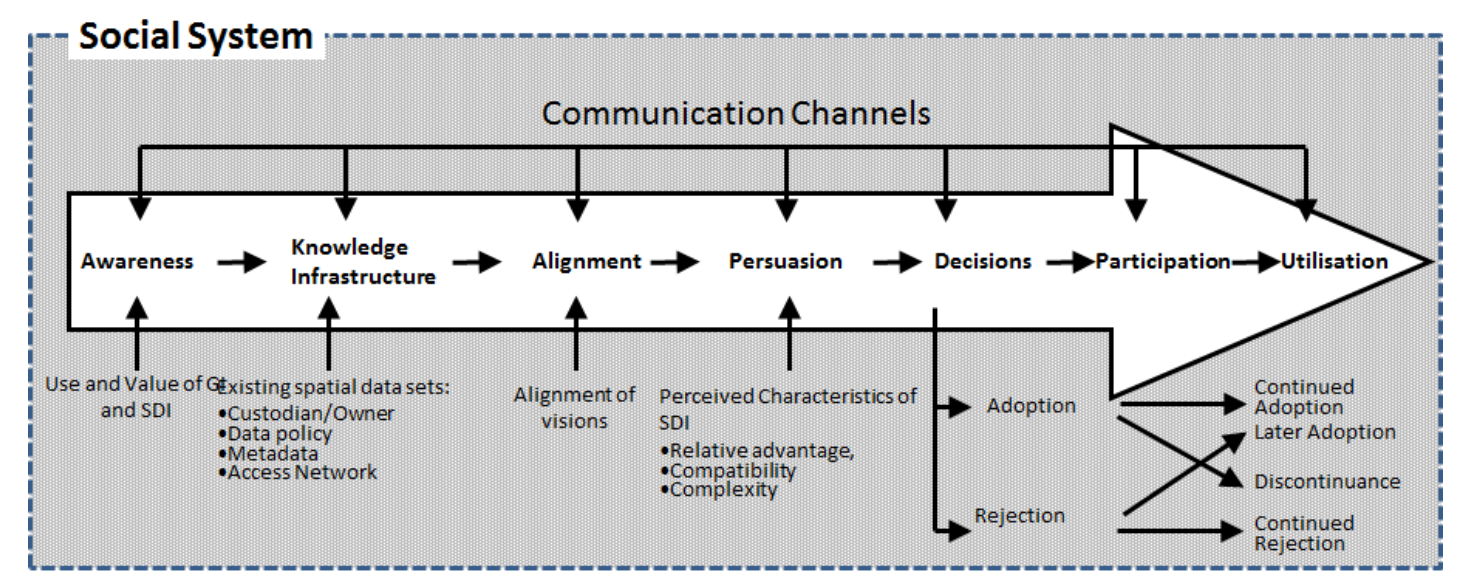

Fig. 2 - Process-based model for SDI development

Next, we present Fig. 4 [7], which Rajabifard, et al. describe as follows: "The local and state levels of an SDI hierarchy are similar to the operational tier of an organizational structure. Both these levels of SDIs are producing data and, are thus, forming data which contributes to higher levels of an SDI hierarchy. However, state level SDIs can play more important roles in a federated system of government, where due to the power and responsibilities of states, state-level SDIs can emulate management or operational organizational tiers, or both, for the entire state. Both management and operational tiers take product-based approaches due to their key roles in data development. Only, the strategic tier and nations with federated systems are suggested here to adopt the process-based model of SDI development. The main reason multinational and federated nations can capitalize on using a process-based model is because of the voluntary nature of SDI participation in these levels of an SDI hierarchy". 


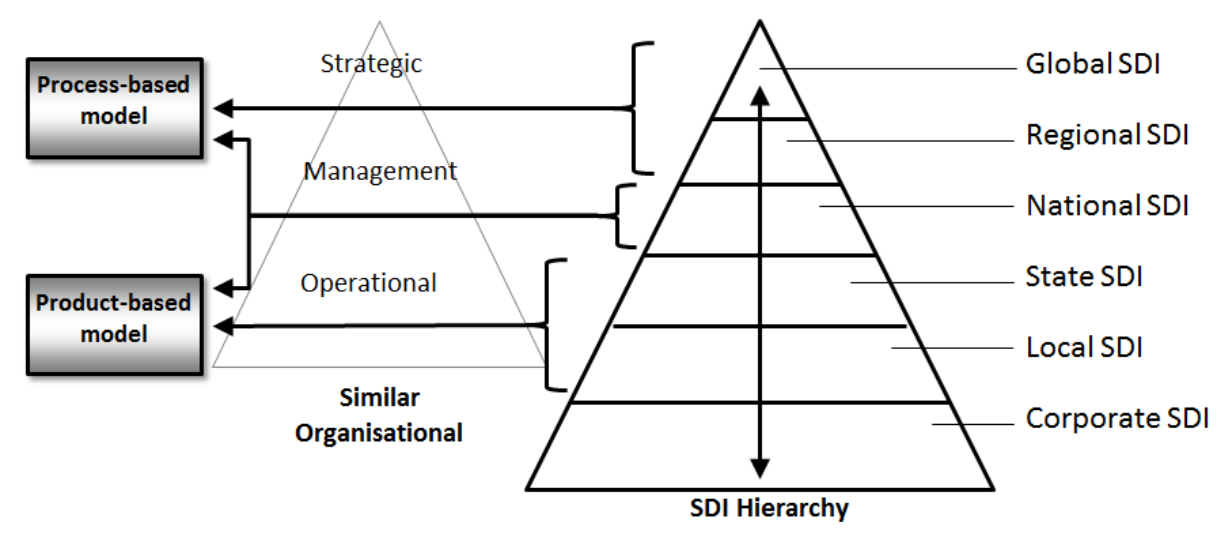

Fig. 3 - Relations between SDI hierarchy and different models of SDI development

For Ukraine, such a change of Fig. 4 is suggested: Regional SDI - INSPIRE, Provincial SDI - Regional SDI, Local SDI - District SDI. However, the notion of a province in Australia or a state in the United States is fundamentally different from the notion of an oblast in Ukraine. Therefore, hierarchy levels below the NSDI level should be treated with caution. The reason for this was explained in the monograph [10]. It denied the need for the NSDI of Ukraine to have regional and district levels in the sense of Fig. 4. This objection did not relate to the possibility to have territorial and/or departmental NSDI nodes if necessary. But the level of INSPIRE was justified as mandatory for the NSDI of Ukraine.

Although it is now 2021, the views Nedovich-Budich, et al. [11] are still relevant, which in the section 'Research and Challenges' note four main limitations of the SDI: 1) northern centrism, 2) the dominance of national level, 3) technical orientation and inadequacy (poverty) of the theory, as well as, 4) lack of methodological diversity and rigor.

We are not able to consider in detail the limitations that can be reformulated as problems of SDI modeling. We also cannot consider all available SDI models in detail. Instead, we have chosen so-called "formalized" SDI models, which can help solve the above problems 1-4 (remove restrictions 1-4) at least in part. Unfortunately, there is not much work on formalized models, so it is enough to dwell on the main ones. 
The first such work is [12]. Fig. 5 presents the philosophy of abstract SDI design. The authors acknowledge that abstract projects (designs) need to be mapped to specific platforms (get Platform-dependent models - PDMs), although they have not done so.
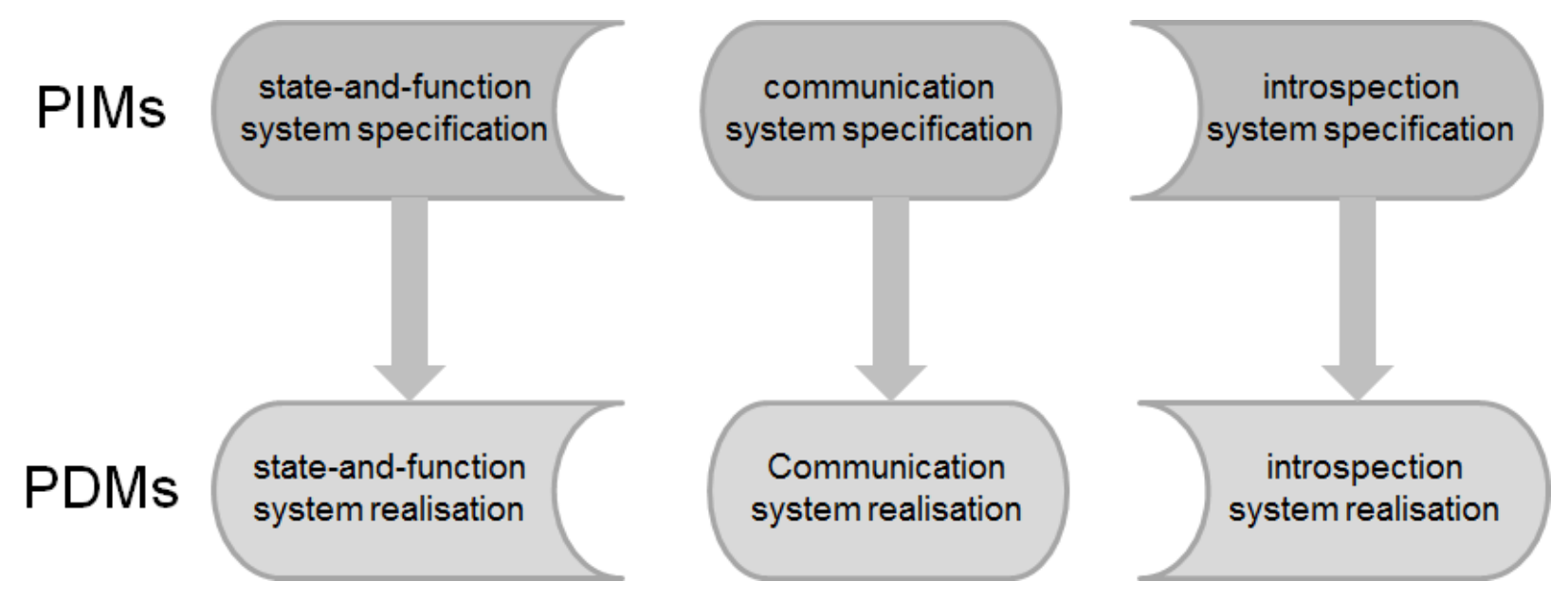

Fig. 4 - Overview of SDI design philosophy [12; Fig. 1]

de By, et al. [12] use several mathematical formalisms to identify the components of the project and the relations that exist between them. This is done in the following sequence:

1. State-and-function system, in which we focus on how to specify an SDI node as a system that holds information, and provides functions that operate on that information. We call this the vertical perspective because such systems are realised often in a software stack.

2. Communication system, in which we focus on how to specify the communication patterns between SDI nodes, abstractly constructing a larger system, the SDI. We call this the horizontal perspective to emphasise peer SDI nodes communicating with each other.

3. Introspective system, in which we focus on augmenting the specified SDI system with means to query itself for service possibilities and allow the dynamic creation of new services.

Another formalized approach we met in 2017, when we participated in the pilot projects "Data Harmonization Pilot in Ukraine" and "National Danube Node Ukraine" [10]. These pilots have created a fragment of the Danube Reference Data and Services Infrastructure (DRDSI) INSPIRE for several relevant regions of 
Ukraine. The German company WeTransform harmonized the basic data for selected territories of Ukraine and Moldova.

WeTransform used [13] the so-called "INSPIRE Model-Driven Approach" (Fig. 6). The description of the approach takes into account that INSPIRE is a directive on the interoperability and availability of geospatial data related to the environment. Interoperability means that different systems are compatible and able to exchange information so that other systems will understand it. There are many different ways to achieve interoperability of computer systems, one of which is the Model-Driven Architecture approach (MDA).

MDA defines a set of instructions for structuring specifications, expressed as models. Using the MDA methodology, the functionality of the system is defined as a Platform-Independent Model (PIM). By creating a common PIM, the INSPIRE community has achieved conceptual interoperability - a common data specification has been created. To achieve operational interoperability, PIM is translated into one or more Platform-Specific Models (PSMs; the same as PDMs in Fig. 5), using implementation languages such as Java, Python, or XML Schema. The model-driven INSPIRE approach is generally explained in Fig. 6. We emphasize that the formalisms of Model-Based Engineering are used here. We recommend the interested reader to read the relevant paragraphs of the monograph [10].

Finally, the third and most important example of a formalized approach to SpIA/NSDI modeling is the Pattern-Based Relational Cartography approach (RelCa, [10]). Let's just say that we will not worry about the description of research methods, because we are only looking for models that are called patterns. According to [14; $\mathrm{p}$. 247] the pattern is at the same time the corresponding method.

Namely, the thing we are researching is "stratified" in terms of knowledge. The most famous names of strata are (bottom-up): Operational, Application, Conceptual, General. The formal basis of stratification is the provisions of the article [15]. The component of each stratum necessarily includes three levels: Datalogical, Infological and Organizational. The formal basis for the allocation of levels is the provisions of the article [16]. The thing can be understood as an Electronic atlas, Atlas information 
system, Carto- information system, Geo- information system. Modern things are Carto-/Geo-information platforms (CIP/GIP) such as Google Maps and/or OpenStreetMap.

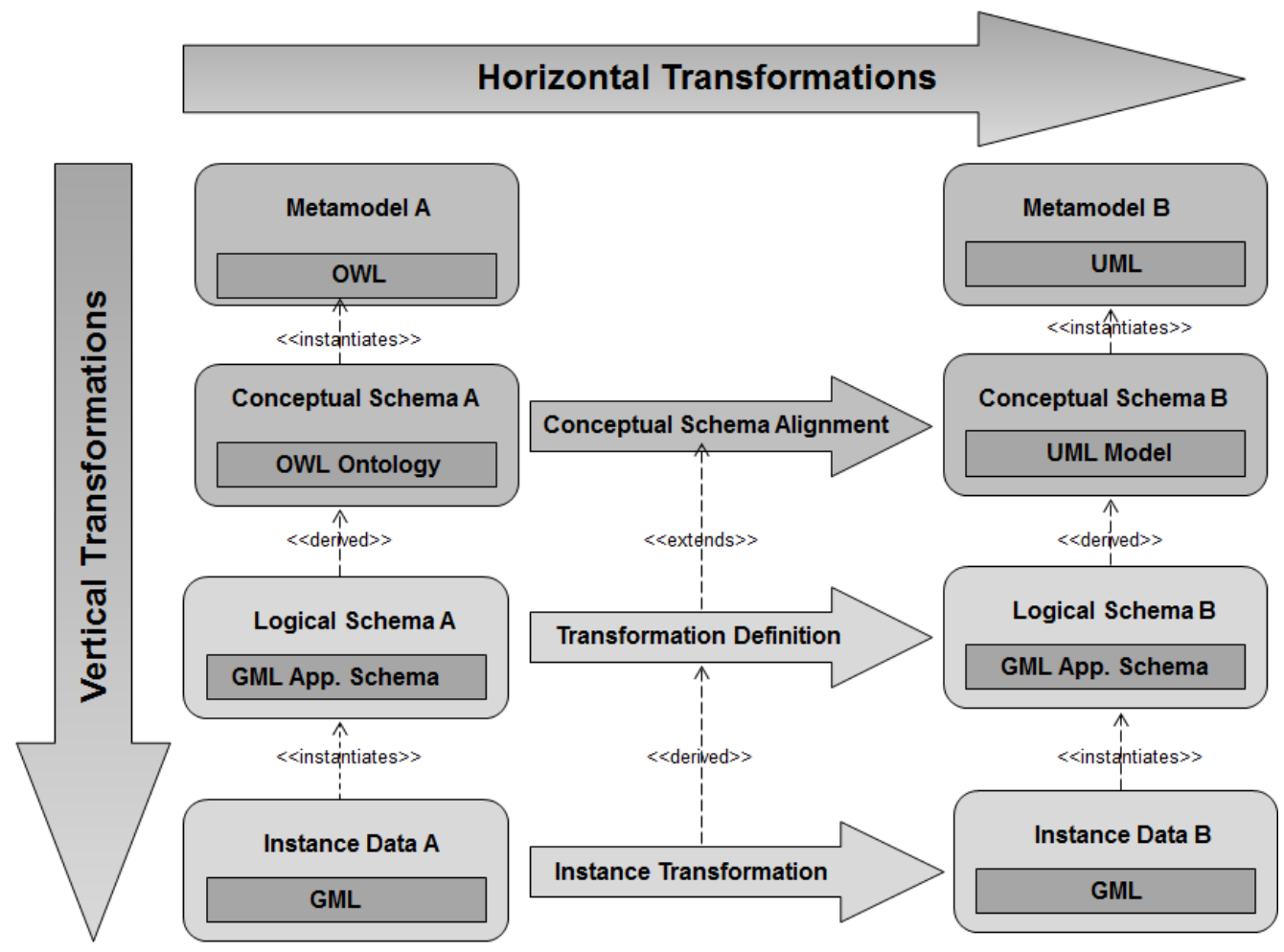

Fig. 6 - Model-driven INSPIRE approach [13]

\section{Actual model of NSDI development in Ukraine}

It follows from the original part of Fig. 1 [3] that some countries of the world have gone through the 2-nd Generation of SDI development and are now in the 3-rd Generation of development. It is quite obvious that the NSDI of Ukraine will not access neither practically nor theoretically the 3rd generation of development. The first proof is the Law [1], from which it follows that even theoretically NSDI of Ukraine will not correspond to the 3rd development model.

Let's pay attention to NSDI users in the 3-rd Generation of its development (Fig. 1): "'Open" countries'," International corporations" and "Closed" countries'. "Open" here are countries in which territories are working the services as Google Maps and/or OSM. Ukraine is such an open country. It is easy to see that, for example, the OSM meets the above definition of the SDI product model. Therefore, OSM in Ukraine is a component of its actual NSDI. 
The product model is the basis of the Law [1]. It seems that its authors decided that the main data sets (products) should be the main ones in the current NGDI of Ukraine and "subordinated" them through the provisions of the Law to the institutional framework, technical standards and network of data exchange centers. In the Law, fundamental data sets are most likely called basic and are defined as 17 . There is no order of operation with these data. Not, as, for example, in INSPIRE where operation has to be carried out alternately, in three turns. In the first turn INSPIRE operation should be carried out "only" with 9 data sets, in the second - with four. Some datasets are very "expensive", so they cannot be a priority due to the obvious lack of funds. For example, "10) engineering communications" are basic data sets according to the Law. In INSPIRE it is "Utility and governmental services" which are carried to the 3 rd turn which is realized after the 2 nd turn. In addition, the data set on the essence of cultural heritage is named thematic in the Law of Ukraine, and in INSPIRE they belong to the $1^{\text {st }}$ turn data sets (basic or fundamental).

From the above information we can conclude that the Law [1] will not be implemented due to its "voluntary" provisions. More precisely, many provisions of the Law depend on the opinion of its possible executors, and this is always dangerous, especially in Ukraine. For example, what happens if executors decide that the main thing is "10) engineering communications" and (always limited) funds should be directed to this data set? At the same time, there is not even such a justification "as in Europe", because in the Law [1] INSPIRE is mentioned only once insignificant.

At the same time, in Ukraine there is already "some" digital NSDI, which corresponds to the product-process and actual model of NSDI development. The main argument for this conclusion is the "usability" of OSM, Google Maps, etc. Moreover, by all Ukrainian users: both individuals and legal entities. It is hardly necessary to clarify the understanding of "some" digital NSDI and its differences from "future" NGDI without a government task, as the result may be unnecessary for government but for the scientific community only. 
The "product-processity" of the actual model of NSDI development is based on the fact that OSM, on the one hand, corresponds not only to the product, but also to the process and even SES models of NSDI development. On the other hand, there are some differences from the "canonical" representations about the "product" model of NSDI. For example, OSM does not operate with land data. And in the Law [1], they belong to the basic data sets (ie, to the fundamental data sets in the definition of the product model) and thus are an element of the product model of NGDI. Thus, the Law [1] can determine the beginning/continuation of the creation of only a "part" of NSDI. Without a detailed analysis, it is difficult to understand to what extent the abstract NGDI model described in the Law [1] corresponds to the real part of the NSDI model.

\section{Correct model of NSDI development in Ukraine}

In 1992, the Conception of the National GIS (NGIS) of Ukraine was developed [17]. If we use the models described above, we can say that it was the Conception of NSDI, which corresponds to the product model. Namely, the Conception of NGIS distinguished scientific-educational, production and management components, which were called subsystems of NGIS: Scientific (SNGIS1), Production (PNGIS1) and Management (MNGIS1). The main component of NGIS1 was PNGIS1, which fully complied with the above four-component definition (product model) of NSDI. Thus, PNGIS1 consisted of three subsystems: 1) National Topographic Data Bank (NTDBn, fundamental data sets), 2) Systems for manipulating exchange standards (technical standards), 3) Systems for receiving/sending requests from/to external GIS/IS (network of data exchange centers). The institutional framework was to be based on the appropriately adjusted normative documents of Ukrgeodescartography and on the activities of the State Commission on GIS, which was established in 1993 at the request of the NGIS project.

PNGIS1, in line with the Conception of NGIS1, has not been fully implemented. However, there is a partial implementation of PNGIS1 in Radioecological GIS (RGIS, [18]). As the Chornobyl accident affected 12 of 
Ukraine's 25 oblasts, we de facto had to create a fragment of the NSDI within the limits of the RGIS. In addition to the PNGIS1 variant, the RGIS1 implemented the MNGIS1 variant, which was called RadEco [18]. Interestingly, the requirements of the practice led to the creation of a publicly available component of RadEco. It became the Atlas of Radioactive Contamination of Ukraine (RadAtlas), which was published in mass circulations in 2002, 2008 and 2011. The variants of PNGIS1 and MNGIS1 implemented in RGIS used non-proprietary components of SNGIS1, which existed in scientific institutions dealing with "Chornobyl" topics.

SNGIS1 and MNGIS1 were integral components of both NGIS1 and NSDI1. Without going into details, let's say that SNGIS1 was supposed to ensure the evolution of NGIS1/NSDI1. MNGIS1 was to become the first application of NGIS1/NSDI1, and, using it directly in the management structures of the country. Unfortunately, this did not happen. Ukrgeodescartography decided to create an Automated Cartographic System (ACS) instead of NTDBn, proposed by the Conception of NGIS1. It should be noted here that the ACS for the internal needs of Ukrgeodescartography is fundamentally different from the NTDBn, intended for both internal users and users outside this organization.

After 1992, several implementations of PNGIS1 and MNGIS1 were performed. In addition to the already mentioned RadEco and RadAtlas MNGIS1, the most famous example of its implementation is the Electronic version of the National Atlas of Ukraine (ElNAUonDVD, [19]) because it significantly uses data from the management structure of the country - Derzhkomstat. This MNGIS1 was operated not only in Derzhkomstat, but thanks to the production of mass circulations of EINAUonDVD (5000 copies in 2007 and 1000 copies in 2010), it was distributed throughout the country.

At the boundary of the millennium, we participated in two defining NSDI projects. In the first (1998-2003), we coordinated three projects of the FrancoGerman Chornobyl Initiative (FGI). There were many sub-projects of 3 FGI projects - about 50 (see [10] and the sources cited there). All of them dealt with the territory of the Chornobyl accident in one way or another, but now for Ukraine, Belarus and 
Russia, which further substantiated the need to use geo-information technologies. To effectively coordinate a large number of sub-projects, we had to develop the so-called Framework of main solutions for FGI (sub-)projects, which became known as the ProSF (Project Solutions Framework).

Almost simultaneously with the FGI, Phase IV of the Swedish-Ukrainian project "Creating conditions for the implementation of NSDI in Ukraine, Phase IV, 2000-2003" was implemented. The FGI experience was used for NSDI. Namely, we thought about the question, what should have companies that implement geoinformation projects, using NSDI elements? The result of these thoughts was the GeoSF (GeoSolutions Framework), which became an evolution of ProSF and was intended for both project and day-to-day operations of geo-enterprises.

GeoSF was proposed in the early 2000s to build a digital NSDI in Ukraine [6]. Then at the state level under the leadership of Ukrgeodescartography (now Ukrgeocadastre) it was necessary to adapt and collect in the Spatial Information System in a certain "broader" sense the existing digital "classic" components of NSDI, supplement them with typical "project" geo-products and geo-services and offer it economically useful way to each geo-enterprise of Ukraine. It was taken into account that at that time in Ukraine there were already digital components, which for a small fee could be easily adapted to make "classic" components of the NSDI of Ukraine, built according to the then relevant in the world product model of NSDI. The same can be said about typical "project" geo-products and geo-services, although formally the latter were already the first step towards process NSDI. Priority for the implementation of GeoSF were geo-enterprises of Ukrgeodescartography.

It is important to note that GeoSF is a Solutions Framework ( $\mathrm{SoFr}$ ), where the SoFr method and means differ. Simplified, the essence of the SoFr method is that to create a specific information object you need to have a model in which you have accumulated basic knowledge about the object itself. There are two important limitations to information objects and models: models must be patterns, and the transition from a model to an object must be an epistemological transition (reduction) only one level down. In this case, the object can be a model, system or just another 
object, and the transition is described by the relations metamodel-model, modelsystem, model-implementation, model-tool, and so on. Another important property of the SoFr method is the dualism of product and process: a product cannot be created without a process, and a process does not make sense without a product being created.

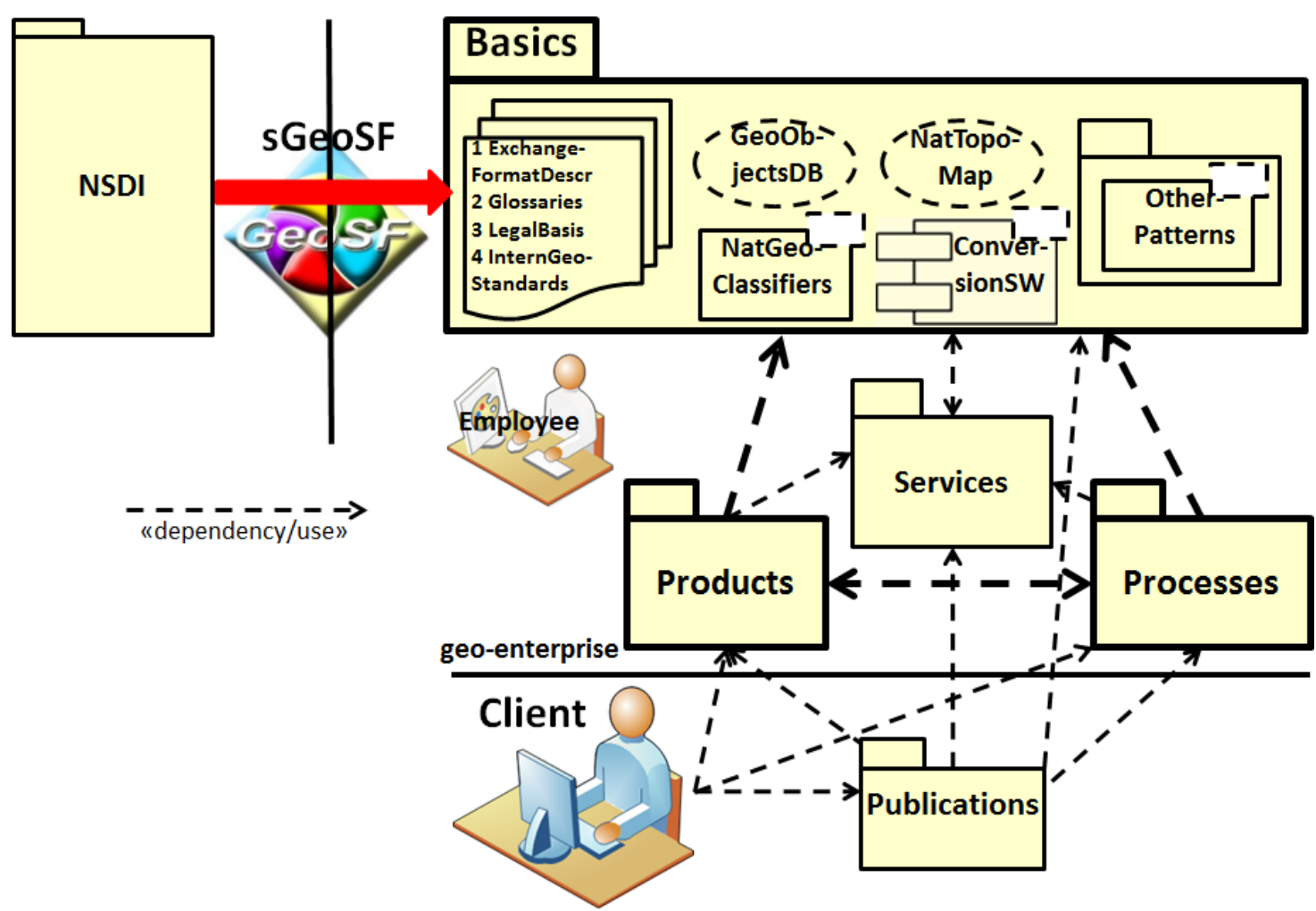

\section{Fig. 7 - Geo-enterprise that supplies or uses geo-products and geo-processes}

Fig. 7 shows, on the one hand, the scheme of the standard (s) GeoSF version sGeoSF. At the beginning of the century it was planned to supply it to geo-enterprises in the form of a portal on the software operating at that time. On the other hand, the scheme of Fig. 7 reflects the essence of both the sGeoSF and any SoFr method. Fig. 7 is 'read' as follows. The geo-enterprise supplies and the customer 'uses' the geoproduct or geo-service. There may be a relation of dependency or use between geoproducts and geo-services (processes). For example, in the case when an enterprise is developing the geographic information systems that should work on MapInfo MapXtreme, the client uses both the geo-service (process) of development and the geo-product MapXtreme. The client can be internal - an employee of the geoenterprise. In this case, we have a geo-enterprise that uses geo-products and/or geoservices (geo-processes). 
The initial pattern system included elements called "classic" NSDI elements. These are primarily elements from the fundamental data sets and technical standards of the product NSDI. Explanation of the Basics package notations on Fig. 7 is shown in Tabl. 1.

\section{Tabl. 1 - Notations of the Basics package on Fig. 7}

\begin{tabular}{|c|c|}
\hline \begin{tabular}{|l} 
NatGeo- \\
classifiers
\end{tabular} & An 'arbitrary' pattern, in this case the National GeoClassifiers pattern \\
\hline ( NatTopo') & Pattern of the National Topographic Map \\
\hline 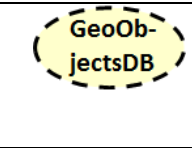 & $\begin{array}{l}\text { Pattern of the database of geoobjects, built using KOATUU - the State } \\
\text { Classifier of Objects of Administrative-Territorial System (division) of } \\
\text { Ukraine }\end{array}$ \\
\hline Sonver- & $\begin{array}{l}\text { Pattern of software for converting vector maps of different formats. In } \\
\text { 2001, it was a MapInfo } \leftrightarrow \text { ArcView conversion }\end{array}$ \\
\hline $\begin{array}{l}\text { TExhange- } \\
\text { FormatDescr } \\
2 \text { Glossaries } \\
3 \text { LegalBasis } \\
4 \text { InternGeo- } \\
\text { Standards } \\
\end{array}$ & $\begin{array}{l}\text { Documents: } 1 \text { - Description of exchange formats, including exchange } \\
\text { formats ArcView and MapInfo, } 2 \text { - Glossaries, } 3 \text { - Electronic versions of } \\
\text { Ukrainian laws and regulations in force in the field of geoinformatics, } \\
\text { current for 2001, } 4 \text { - Description of international standards in the field of } \\
\text { geoinformatics, etc. }\end{array}$ \\
\hline \begin{tabular}{l|} 
\\
$\begin{array}{c}\text { Other- } \\
\text { Patterns } \\
\text { Pats }\end{array}$
\end{tabular} & $\begin{array}{l}\text { In addition to the "classic elements of NSDI", sGeoSF included patterns and } \\
\text { mechanisms for Products, Processes, Publications and Services of the geo- } \\
\text { enterprise. }\end{array}$ \\
\hline
\end{tabular}

Highlighted in bold arrows in Fig. 7 also represent the so-called main triad of each SoFr - the relations between the components of the Products, Processes and Basics packages. The "classic" components of the sGeoSF package are examples of components that are in a dependency/use relation with the components of the Products package. For example, in the manufacture of EINAU [19] we used the national topomap of Ukraine, but indirectly. In fact, the so-called typical "project" geo-product was used - the "project" national topomap. This map was a transformation of the national topomap of the NSDI into a topographic map, which was used in the project of creation of EINAU, as well as in other similar projects.

The project national topomap was usually used together with one or more thematic layers. If you imagine samples of such thematic maps, then we get an idea of the contents of the package with OtherPatterns parameterized objects in Fig. 7. In fact, we gave an example of the relation: "specific thematic map" uses "sample thematic map". Among OtherPatterns there were samples of maps creation processes therefore we consider clear contents of a Processes package. 
It turned out that the main SoFr Products-Processes-Basics triad and/or the Products-Processes-Basics-Services-Publications pentagram are powerful constructions that are often found in any geo-information activity. For the main triad, we can say that the ambiguity of at least one of the three components calls into question the success of any geo-information activity, regardless of the geo-product to be created or the geo-process to be performed.

SoFr pentagram can be represented as in Fig. 8a, where the main SoFr triad is highlighted by bold lines in the same way as in Fig. 7. Apparently, a better understanding of the main SoFr triad will allow Fig. $\mathbf{8 b}$. The relation between Models (Basics package) and Systems (Product, Process packages) includes the conformity relation, which is implemented in particular using the "meta-step" pattern [20].

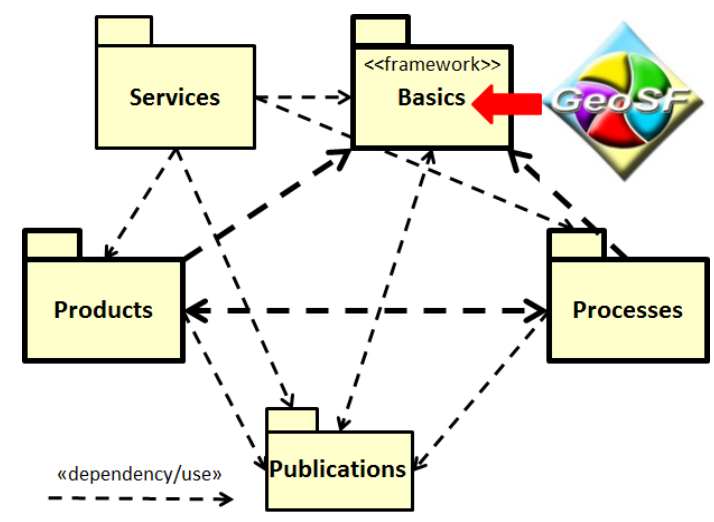

a) Inverted SoFr pentagram

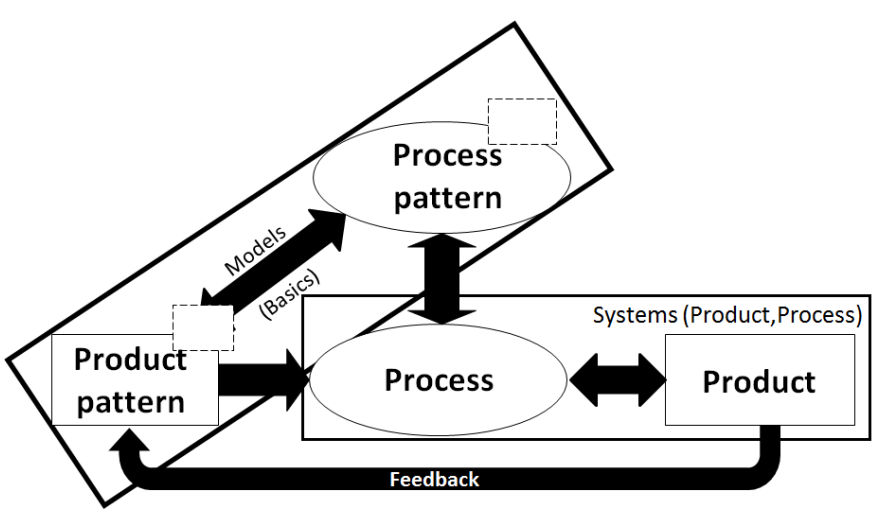

b) Simplified representation of SoFr triad

\section{Fig. 8 - The main triad of SoFr: Products-Processes-Basics(Products,Processes)}

NGIS1 is consistent with the formation of Web 1.0 [10]. SNGIS1, PNGIS1 and MNGIS1 evolved into the Web 1.0x1.0 (Web 1.02) formation. Thus, we have created an "ㅅtlas of the Population of Ukraine and its Natural and Cultural Heritage" $(\mathrm{APN} \& \mathrm{CH})$ in the architecture of Web 1.0+ [21]. APN\&CH has two implementations: APN\&CH2016 - in the formation of Web 1.0, APN\&CH2018 - in the formation of Web $1.0^{2}$. Thanks to APN\&CH2018, the statement for MNGIS1 evolution has been proven. PNGIS1 already has several Web 1.0x1.0 implementations in Ukraine. Suffice it to give an example of a Ukrainian fragment of OSM. There are evidences of the possibility of SNGIS1 evolution in Web 1.0x1.0. Denote the current versions of these subsystems SNGIS1.0x1.0, PNGIS1.0x1.0, 
MNGIS1.0x1.0 (and NGIS1.0x1.0 in general). The structure of the modern NSDI of Ukraine (NSDI2017) is shown in Fig. 9 [10].

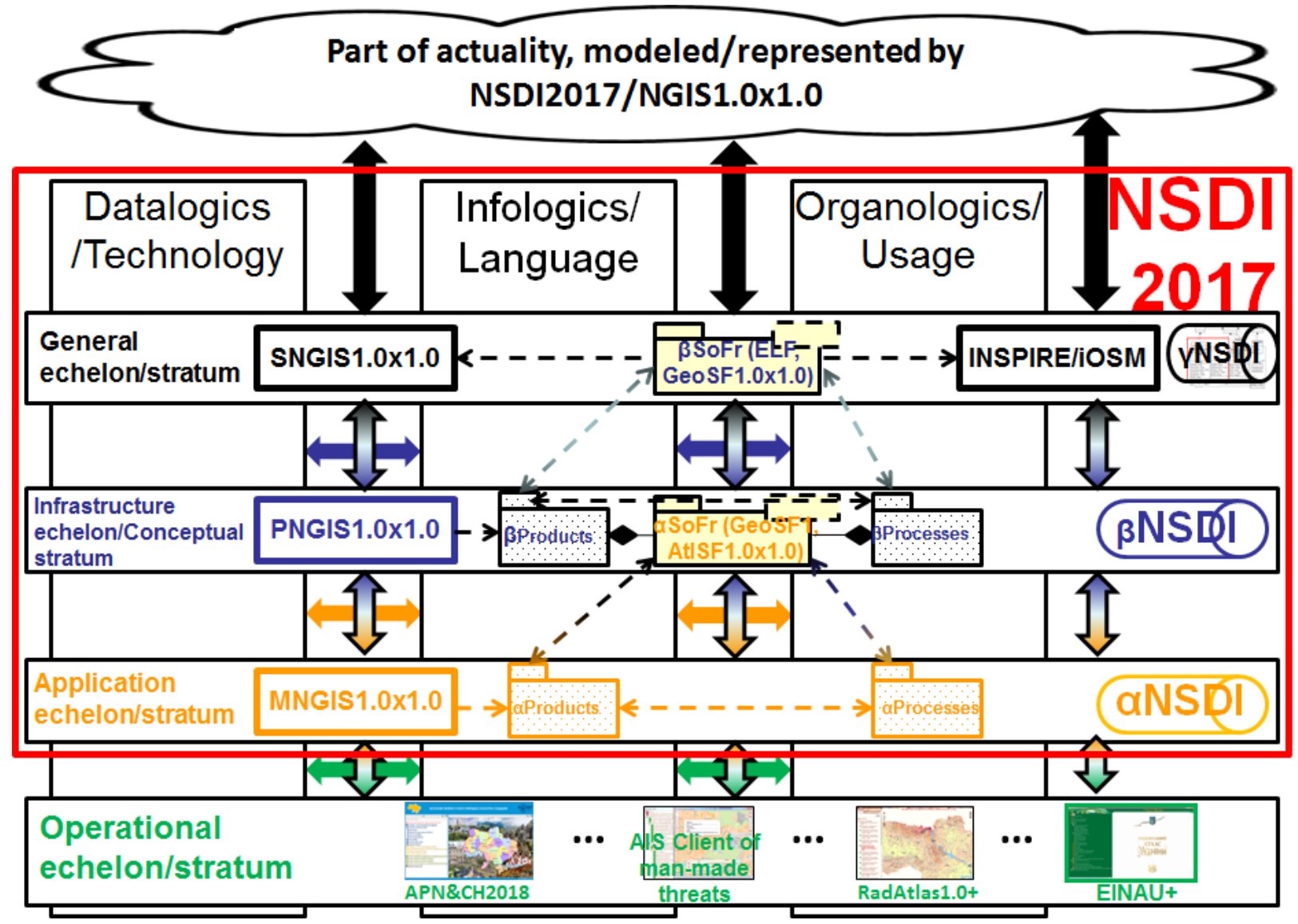

Fig. 9 - Product-process structure of NSDI2017 ("correct" model)

Explanation of NSDI2017 abbreviations: 1) iOSM - OpenStreetMap infrastructure (includes OSM), 2) $\beta \mathrm{SoFr}$ - main triad of infrastructure (conceptual) Solutions Frameworks, for example, ELF (European Location Frameworks), GeoSF1.0x1.0 (Web 1.0 ${ }^{2}$ GeoSolutions Framework), 3) $\alpha \mathrm{SoFr}$ - the main triad of application Solutions Frameworks, for example, AtlSF1.0x1.0 (Web 1.0 ${ }^{2}$ Atlas Solutions Framework), GeoSF1.0. Dotted arrows here indicate the relation of dependence. Solutions Frameworks (SoFr) are constructors that allow constructing lower echelon/stratum products and processes relative to the top of the triad. The top of the $\beta$ SoFr triad depends on both the SDI INSPIRE/iOSM and the SNGIS1.0x1.0. The blue color of the name of this top of the triad means here its purpose to meet the needs of creating products and processes of the lower stratum. Shown in Fig. 9 components and relations consist of more detailed. The $\beta \mathrm{SoFr}$ and $\alpha \mathrm{SoFr}$ components ensure the processes and evolution of Ukraine's NSDI within its NSDI2017 model. 
The Operational echelon/stratum shows two modern atlases as examples: APN\&CH2018 and AIS (Atlas Information System) Client of man-made threats, as well as two potentially possible atlases in the near future: RadAtlas $1.0+$ and EINAU1.0+. APN\&CH2018 was released in 2020 [21]. AIS of man-made threats is being developed at the Institute of Geography now with the expected public result at the end of 2021. RadAtlas1.0+ and ElNAU1.0+ are possible next versions of RadAtlas1.0 and EINAUonDVD. The basic characteristic of versions 1.0+ should be dynamics (processes).

In the context of this work, the most important construct of NSDI2017 is SoFr, because they allow to consider the model of NSDI2017 not only product (through Products), but also process (through Processes). In general, at first any SoFr was represented by a direct pentagram [6]. If we take into account the Conceptual Framework (CoFr) of RelCa [10], it is better to represent SoFr in an inverted pentagram as in Fig. 8a.

Due to the conformity of the NSDI model and system, as well as due to the search among the models of patterns, we can apply induction and deduction to conclude about the "correctness" of the NSDI2017 model. Namely, in the monograph [10] the inductive method of analogies was applied to EINAU CoFr to obtain the NSDI2017 model. On the other hand, both many components and the NSDI2017 itself can be obtained by deduction from the relevant constructions of Model-based engineering. Moreover, according to [22] we can talk about a constructive (or normative as an alternative to the declarative) method of NSDI2017 digital system development.

At the end of the article it is expedient to indicate that in Chapter 8 monographs [10] are proposed and substantiated 5 static (S) and 4 dynamic (D) principles of the NSDI of Ukraine creating:

- S1. Design, not improve.

- S2. Classification (federative system), not generalization (unitary system).

- S3. 'Three-context' harmonization.

- S4. Open solutions.

- S5. At least one custom application. 
- D1. Conceptual Solutions frameworks as constructors of elements of infrastructure echelon/conceptual stratum.

- D2. Application Solutions frameworks as constructors of user applications.

- D3. The correct start is "Orientation on the boundaries of BaseMap CoFr".

- D4. Conceptual framework of NSDI as a SES constructor in Ukraine.

The essence of the principles of S1-S5 is explained in the article [23] in 2017. In the years since the publication of the article [23] and the monograph [10], these principles should have been updated. However, in 5 years, serious questions among the $\mathrm{C} 1-\mathrm{C} 5$ principles have arisen only to the $\mathrm{C} 4$ principle. The fact is that the ELF project today already seems a failure (see its place in the NSDI2017 architecture on Fig. 9). In the years after the publication of the monograph [10] it is necessary to update these principles. At the moment there are only questions to S4. We will not hide that the ELF project currently seems to be a failure (see Fig. 9). Remind that it was based on Oskari Map Application Platform technology [24]. In parallel and very aggressively, ESRI, Inc. offered to use their ArcGIS technology. Apparently, a separate article is needed to explain that the S4 principle is still valid for NSDI of Ukraine and for regional SDI, such as INSPIRE.

Over the past 5 years, the principles of D1-D4 have not been updated, but clarified. Thus, the essence of the D3 principle in addition to the monograph [10] is explained in this year's article [25] on the example of dealing with the boundaries of objects of tangible cultural heritage. The essence of the principle D1 is specified in this article. In the Web 1.0 formation, GeoSolutions Framework GeoSF1.0 was conceptual SoFr. In the Web 1.0x1.0 formation, it evolved into GeoSF1.0x1.0. There are additional arguments for the feasibility of this correct model of NSDI of Ukraine development.

\section{Conclusions}

Models of NSDI development in Ukraine, "actual" now and "correct" in the next five years, are described. Both models are so called product-process. The product-process model of NSDI development in Ukraine (Fig. 9) is named "correct", because CoFr 
and SoFr patterns are proved in Relational cartography (RelCa) with sufficient formalization.

NSDI2017 must correspond to the 5 static (S) and 4 dynamic (D) principles of the NSDI development, formulated in main part of the article. Specified principles are not necessary and sufficient for the successful development of the NSDI of Ukraine. However, failure to comply with at least one static or dynamic principle is likely to lead to project or system failure.

\section{Literature}

1. Pro nazionalnu infrastructuru geoprostotovyh danyh: Zakon Ukrainy №554IX [Law of Ukraine "On National Infrastructure of Geospatial Data"] (2020). Vidomosti Verhovnoi Rady, 37, p. 277 Available at: (accessed 2021-jun-26) https://zakon.rada.gov.ua/laws/show/554-20\#Text. (Ukrainian)

2. Hendriks Paul H.J., Dessers Ezra, van Hootegem Geert. (2012) Reconsidering the Definition of a Spatial Data Infrastructure.- International Journal of Geographical Information Science, 2012, 26, 8, 1479-1494.

3. Rajabifard A., Binns A., Masser I., Williamson I.P. (2006) The role of subnational government and the private sector in future SDIs.- International Journal of Geographical Information Science, Vol. 20, Iss. 7, pp. 727-741.

4. Steudler Daniel, Rajabifard Abbas, Editors. (2012) Spatially Enabled Society. FIG report No. 58.- The International Federation of Surveyors (FIG), 2014.$68(72) \mathrm{p}$.

5. Rajabifard A., Williamson I.P. (2002) Spatial Data Infrastructures: an initiative to facilitate spatial data sharing, 30 p. / in Global Environmental Databases Present Situation; Future Directions - Volume 2.- Hong Kong: International Society for Photogrammetry and Remote Sensing (ISPRS-WG IV/8), GeoCarto International Centre.

6. Dyshlyk, O.P., Markov, S.Ju., Chabaniuk, V.S. (2003). Karkas georishen' jak sposib pobudovy natsional'noi infrastruktury geoprostorovyh danyh [The framework of geosolutions as a way to build a national infrastructure of geospatial 
data]. Research and technology collection: Engineering geodesy, 49. Kyiv: KNUBiA, 73-94. (Ukrainian)

7. Rajabifard Abbas, Feeney Mary-Ellen, Williamson Ian P. (2002) Future Directions for the Development of Spatial Data Infrastructure.- International Journal of Applied Earth Observation and Geoinformation, 4, pp. 11-22.

8. Rogers Everett M. (2003) Diffusion of Innovations.- Free Press, 5th Ed., 576 p.

9. Rogers Everett M. M. (2009) Dyfuziya innovatsiy [Diffusion of Innovations].- K.: Publ. house 'Kyiv-Mohyla Academy', (Free Press, 2003, 5th Ed) .591 p. (Ukrainian)

10. Chabaniuk, V.S. (2018). Relyaziyna kartografiya: Teoriya I praktyka [Relational cartography: Theory and practice]. Institute of geography NANU. Kyiv, 525. (Ukrainian)

11. Nedovich-Budich Zorica, Crompvoets Joep, Georgiadou Yola, Eds. (2011) Spatial Data Infrastructures In Context: North and South.- CRC Press. 254 (290) p.

12. Rolf A. de By, Rob Lemmens, Javier Morales (2009) A skeleton design theory for spatial data infrastructure. Methodical construction of SDI nodes and SDI networks.- Earth Sci Inform 2: 299-313.

13. Reitz Thorsten. (2016) DRDSI Data Harmonization Project.- http://drdsipilot.wetransform.to/index.html, accessed 2021-jun-16. See also INSPIRE Data Specification Extensions (2016).- http://inspire-extensions.wetransform.to, accessed 2021-jun-16.

14. Alexander Christopher. (1979) The Timeless Way Of Building.- Oxford University Press. 552 p.

15. Bergheim Geir, Sandersen Erik, Solvberg Arne. (1989) A Taxonomy of Concepts for the Science of Information Systems, pp. 269-323 // Falkenberg Eckhard D., Lindgreen Paul, Eds. Information System Concepts: An In-depth Analysis.North-Holland, 357 p. 
16. Iivari Juhari. (1989) Levels of abstraction as a conceptual framework for an information system, pp. 323-352 // Falkenberg Eckhard D., Lindgreen Paul, Eds. Information System Concepts: An In-depth Analysis.- North-Holland. 357 p.

17. Rudenko L.G. Chabaniuk V.S. (1994) Osnovy contseptsii bagatotsilovoi GIS Ukrainy [Fundamentals of the concept of multi-purpose GIS of Ukraine].Ukrainian Geographical Journal, № 3, p. 22-34. (Ukrainian)

18. Chabaniuk V., Kolimasov I. (2020) Analysis of the Practical Use of Geoinformation Systems for Territorial Management and Determination of their Critical Properties.- Cybernetics and Computer Engineering, № 2(200), pp. 5-26.

19. L.G. Rudenko, A.I. Bochkovs'ka, T.I. Kozachenko, H.O. Parkhomenko, V.P. Razov, D.O. Lyashenko, V.S. Chabaniuk / Za red. L.H. Rudenka (2007) Natsional'nyy atlas Ukrayiny. Naukovi osnovy stvorennya ta yikh realizatsiya. [National Atlas of Ukraine. Scientific bases of creation and their realization.]. K .: Academperiodics. 408 p. (Ukrainian)

20. Favre Jean-Marie. (2006) Megamodelling and Etymology. A Story of Words: from MED to MDE via MODEL in Five Millenniums.- Dagstuhl Seminar Proceedings 05161, paper 427, $22 \mathrm{p}$.

21. Rudenko L.G., Bochkovs'ka A.I., Polyvach K.A., Chabaniuk V.S., Santalova S.O., Podvoys'ka V.I., Leyberyuk O.M., Vyshnya M.M., Barabash T.M., Kyrylyuk M.O. (2020) Naselennya Ukrayiny ta yoho pryrodna i kul'turna spadshchyna $v$ atlasniy informatsiyniy [The population of Ukraine and its natural and cultural heritage in the atlas information system.]. Ukrainian Geographical Journal, № 4, p. 58-70. (Ukrainian)

22. Iivari Juhani. (2015) Distinguishing and contrasting two strategies for design science research.- European Journal of Information Systems, Vol. 24, Iss. 1, pp. 107-115.

23. Chabaniuk V., Dyshlyk O. (2017) Obgruntuvannya strukturnykh pryntsypiv pobudovy IPD metodamy Relyatsiynoyi kartohrafiyi, s. 102-113 // Suchasni dosyahnennya heodezychnoyi nauky ta vyrobnytstva. Zbirnyk naukovykh prats' Zakhidnoho heodezychnoho tovarystva UTHK, Vypusk II (34) [Substantiation 
of structural principles of IPD construction by methods of Relational cartography, $\mathrm{p}$. 102-113 // Modern achievements of geodetic science and production. Collection of scientific works of the Western Geodetic Society UTGC, Issue II (34)].- Lviv: Lviv Polytechnic Publishing House, 138 p.

24. Tekhnolohiya [Technology] Oskari Map Application Platform (accessed 2021-чljun-26, https://oskari.org/)

25. Chabaniuk Viktor, Dyshlyk Oleksandr, Polyvach Kateryna, Pioro Vlad. (2021) Boundaries handling as the most correct dynamic principle of the beginning the register of immovable cultural entities creation.- Землеустрій, кадастр i моніторинг земель / Land management, cadastre and land monitoring, No. 1, 23 p. (Ukrainian, English).

\section{Лiтература}

1. Закон України «Про НІГД». Закон України «Про національну інфраструктуру геопросторових даних».- Відомості Верховної Ради (ВВР), 2020, № 37, ст. 277; https://zakon.rada.gov.ua/laws/show/554-20\#Tехt, доступ 2021-чер-26.

2. Hendriks Paul H.J., Dessers Ezra, van Hootegem Geert. (2012) Reconsidering the Definition of a Spatial Data Infrastructure.- International Journal of Geographical Information Science, 2012, 26, 8, 1479-1494.

3. Rajabifard A., Binns A., Masser I., Williamson I.P. (2006) The role of subnational government and the private sector in future SDIs.- International Journal of Geographical Information Science, Vol. 20, Iss. 7, pp. 727-741.

4. Steudler Daniel, Rajabifard Abbas, Editors. (2012) Spatially Enabled Society. FIG report No. 58.- The International Federation of Surveyors (FIG), 2014.$68(72) \mathrm{p}$.

5. Rajabifard A., Williamson I.P. (2002) Spatial Data Infrastructures: an initiative to facilitate spatial data sharing, 30 p. / in Global Environmental Databases Present Situation; Future Directions - Volume 2.- Hong Kong: International Society 
for Photogrammetry and Remote Sensing (ISPRS-WG IV/8), GeoCarto International Centre.

6. Дишлик О.П., Марков С.Ю., Чабанюк В.С. (2003) Каркас георішень як спосіб побудови національної інфраструктури геопросторових даних, с. 73-94 // Науково-технічний збірник: Інженерна геодезія. Вип. 49.- Київ: КНУБіА

7. Rajabifard Abbas, Feeney Mary-Ellen, Williamson Ian P. (2002) Future Directions for the Development of Spatial Data Infrastructure.- International Journal of Applied Earth Observation and Geoinformation, 4, pp. 11-22.

8. Rogers Everett M. (2003) Diffusion of Innovations.- Free Press, 5th Ed., 576 p.

9. Роджерс Еверетт М. (2009) Дифузія інновацій.- К.: Вид. дім 'КиєвоМогилянська Академія', (Free Press, 2003, 5th Ed).- 591 c.

10. Чабанюк В.С. (2018) Реляційна картографія: Теорія та практика.- Київ: Інститут географії НАН України, 525 с.

11. Nedovich-Budich Zorica, Crompvoets Joep, Georgiadou Yola, Eds. (2011) Spatial Data Infrastructures In Context: North and South.- CRC Press. 254 (290) p.

12. Rolf A. de By, Rob Lemmens, Javier Morales (2009) A skeleton design theory for spatial data infrastructure. Methodical construction of SDI nodes and SDI networks.- Earth Sci Inform 2: 299-313.

13. Reitz Thorsten. (2016) DRDSI Data Harmonization Project.- http://drdsipilot.wetransform.to/index.html, доступ 2021-чер-16. Див. також INSPIRE Data Specification Extensions (2016).- http://inspire-extensions.wetransform.to, доступ 2021-чер-16.

14. Alexander Christopher. (1979) The Timeless Way Of Building.- Oxford University Press. 552 p.

15. Bergheim Geir, Sandersen Erik, Solvberg Arne. (1989) A Taxonomy of Concepts for the Science of Information Systems, pp. 269-323 // Falkenberg Eckhard D., Lindgreen Paul, Eds. Information System Concepts: An In-depth Analysis.North-Holland, 357 p. 
16. Iivari Juhari. (1989) Levels of abstraction as a conceptual framework for an information system, pp. 323-352 // Falkenberg Eckhard D., Lindgreen Paul, Eds. Information System Concepts: An In-depth Analysis.- North-Holland. 357 p.

17. Руденко Л.Г., Чабанюк В.С. (1994) Основи концепції багатоцільової ГІС України.- Український географічний журнал, № 3, с. 22-34.

18. Chabaniuk V., Kolimasov I. (2020) Analysis of the Practical Use of Geoinformation Systems for Territorial Management and Determination of their Critical Properties.- Cybernetics and Computer Engineering, № 2(200), pp. 5-26.

19. Л.Г. Руденко, А.І. Бочковська, Т.І. Козаченко, Г.О. Пархоменко, В.П. Разов, Д.О. Ляшенко, В.С. Чабанюк / За ред. Л.Г. Руденка (2007) Національний атлас України. Наукові основи створення та їх реалізація. К.: Академперіодика. $408 \mathrm{c}$.

20. Favre Jean-Marie. (2006) Megamodelling and Etymology. A Story of Words: from MED to MDE via MODEL in Five Millenniums.- Dagstuhl Seminar Proceedings 05161, paper 427, 22 p.

21. Руденко Л.Г., Бочковська А.І., Поливач К.А., Чабанюк В.С., Санталова С.О., Подвойська В.І., Лейберюк О.М., Вишня М.М., Барабаш Т.М., Кирилюк M.O. (2020) Населення України та його природна і культурна спадщина в атласній інформаційній системі.- Український географічний журнал, № 4, с. 5870.

22. Iivari Juhani. (2015) Distinguishing and contrasting two strategies for design science research.- European Journal of Information Systems, Vol. 24, Iss. 1, pp. 107-115.

23. Чабанюк В., Дишлик О. (2017) Обгрунтування структурних принципів побудови ІПД методами Реляційної картографії, с. 102-113 // Сучасні досягнення геодезичної науки та виробництва. Збірник наукових праць Західного геодезичного товариства УТГК, Випуск II (34).- Львів: Видавництво Львівської політехніки, 138 с.

24. Технологія Oskari Map Application Platform (доступ 2021-чер-26, https://oskari.org/). 
25. Chabaniuk Viktor, Dyshlyk Oleksandr, Polyvach Kateryna, Pioro Vlad. (2021) Boundaries handling as the most correct dynamic principle of the beginning the register of immovable cultural entities creation.- Землеустрій, кадастр i моніторинг земель / Land management, cadastre and land monitoring, No. 1, 23 p. (Ukrainian, English).

Чабанюк В.С., Дышлык А.П.

НАЦИОНАЛЬНАЯ ИНФРАСТРУКТУРА ПРОСТРАНСТВЕННЫХ ДАННЫХ (НИПД) УКРАИНЫ: КАКОВЫ ЕЕ АКТУАЛЬНАЯ, РЕАЛИЗУЕМАЯ И ОДНОВРЕМЕННО «ПРАВИЛЬНАЯ» МОДЕЛИ?

В работе рассмотрены актуальная, реализуемая и одновременно «правильная» модели цифровой НИПД Украины. Актуальная модель соответствует существующей ицировой системе НИПД Украины. Эта модель уже сейчас отличается от модели, заданной в Законе Украины «О НИГД» [1]. Поскольку последняя вряд ли в ближайшее время будет реализована, то особенно остро стоит вопрос реализуемой в ближайшие пять лет модели цифровой НИПд Украины, которая бы учитывала актуальную модель. Кроме реализуемости, нужно, чтобы такая модель была еще $u$ «правильной». Такая модель предложена в статье. Правильной называется модель, истинность которой можно установить с помощью индуктивных или дедуктивных умозаключений. Для этого правильная модель должна быть достаточно формализованной, чтобы каждый смог проверить умозаключения авторов независимо.

Понимание как актуальной, так и правильной моделей НИПД Украинь поможет правильно организовать и развить актуальную Пространственную инфраструктурную деятельность (ПрИД) в Украине, включая реальное исполнение Закона [1]. Хотя результаты статьи подвергают сомнениям его

\footnotetext{
2 Реальный. 1. Который существует в действительности, настоящий. Исп. со сл.: действительность, жизнь, существование, условия, обстоятельства, факт, опасность, сила, заработная плата, доходы населения. 2. Такой, который можно осуществить, выполнить: реальный план, реальная программа, реальная задача, реальный срок. 3. Который основывается на учете и оценке настоящих условий действительности: реальный подход, реальный взгляд, реальная политика.- http://slovopedia.org.ua/32/53408/32016.html, доступ 2021-июл-04
} 
осущуествимость и обосновывают альтернативную точку зрения на проблему автоматизаччии НИГД/НИПД/ПрИД. Однако, мы уверены, что альтернативную точку зрения все ещзе возможно изменить на кооперативную, если с помощьью подзаконных актов согласовать модели НИГД (Закон), НИПД (статья) и, наконец, ПрИД.

Для доказательства «правильности» осуществимой модели НИПД используется теория Релящионной картографии и ее два основных метода: Кониеептуальных каркасов и Каркасов решений. Кроме того, использована связь Реляциионой картографии с Базирующейся на моделях инженерией.

Ключевые слова: НИПД; продуктовая модель; прочессная модель; актуальная, реализуемая и «правильная» модель

Чабанюк В.С., Дишлик О.П.

НАЦІОНАЛЬНА ІНФРАСТРУКТУРА ПРОСТОРОВИХ ДАНИХ (НІПД) УКРАЇНИ: ЯКИМИ С Ї̈̈ АКТУАЛЬНА, ЗДІЙСНЕННА І ОДНОЧАСНО "ПРАВИЛЬНА" МОДЕЛІ?

У роботі розглянуті актуальна, здійсненна $і$ одночасно «правильна» моделі цุифрової НІПД Украӥни. Актуальною є модель існуючой цуифрової системи НІПД України. Ця модель вже зараз відрізняється від моделі, заданої в Законі Украӥни «Про НІГД» [1]. Оскільки остання навряд чи найближчим часом буде реалізована, то особливо гострим є питання здійсненної у найближчі n'ять років моделі ичифрової НІПД України, яка б враховувала актуальну модель. Крім здійсненності, потрібно, щуоб така модель була щуе й «правильною». Така модель запропонована у статті. Правильною називається модель, істинність якої можливо встановити за допомогою індуктивних або дедуктивних умовиводів. Для цуього правильна модель повинна бути достатньо формалізованою, щуоб кожний зміг перевірити умовиводи авторів незалежно.

Розуміння як актуальної, так $і$ правильної моделей НІПД України допоможе правильно організувати $і$ розвинути актуальну Просторову 
інфраструктурну діяльність (ПрІД) в Украӥні, включаючи реальне виконання Закону [1]. Хоча результати статті піддають сумнівам його здійсненність $i$ обтрунтовують альтернативну точку зору на проблему автоматизаиії НІГД/НІПД/ПрІД. Однак, ми впевнені, щэо альтернативну точку зору все щее можливо змінити на кооперативну, якщо за допомогою підзаконних актів узгодити моделі НІГД (Закон), НІПД (стаття) i, нарешті, ПрІД.

Для доведення «правильності» здійсненної моделі НІПД використовується теорія Реляиійної картографії і ї два основних методи: Концептуальних каркасів і Каркасів рімень. Крім того, використано зв'язок Реляиійної картографії з Базованою на моделях інженерією.

Ключові слова: НІПД; продуктова модель; прочесна модель; актуальна, здійсненна $i$ «правильна» модель

${ }^{3}$ Реальний. 1. Який існує в дійсності, справжній. Вж. зі сл.: дійсність, життя, існування, умови, обставини, факт, небезпека, сила, заробітна плата, доходи населення. 2. Такий, який можна здійснити, виконати: реальний план, реальна програма, реальне завдання, реальний термін. 3. Який грунтується на врахуванні й оцінці справжніх умов дійсності: реальний підхід, реальний погляд, реальна політика.- http://slovopedia.org.ua/32/53408/32016.html, доступ 2021-лип-04 